\title{
Correction to: A proteome-wide immuno-mass spectrometric identification of serum autoantibodies
}

Milena Music ${ }^{1}$, Antoninus Soosaipillai ${ }^{2}$, Ihor Batruch², Ioannis Prassas ${ }^{2}$, Dimitrios P. Bogdanos ${ }^{3}$ and Eleftherios P. Diamandis ${ }^{1,2,4,5^{*}}$ (1)

\section{Correction to: Clin Proteom (2019) 16:25} https://doi.org/10.1186/s12014-019-9246-0

In the original version of the article [1], an error was noticed under the heading "Immunoprecipitation on protein G magnetic beads" in "Methods" section. The unit symbol in the text that reads as "> $27 \mu \mathrm{l}$ human" should read as "> $27 \mu \mathrm{g}$ human".

\begin{abstract}
Author details
1 Department of Laboratory Medicine and Pathobiology, University of Toronto, Toronto, Canada. ${ }^{2}$ Department of Pathology and Laboratory Medicine, Mount Sinai Hospital, 60 Murray St [Box 32]; Flr 6 - Rm L6-201-1, Toronto, ON M5T 3L9, Canada. ${ }^{3}$ Department of Rheumatology and Clinical Immunology, Faculty of Medicine, School of Health Sciences, University of Thessaly, Biopolis, 41110 Larissa, Greece. ${ }^{4}$ Department of Clinical Biochemistry, University Health Network, Toronto, Canada. ${ }^{5}$ Lunenfeld-Tanenbaum Research Institute, Mount Sinai Hospital, 60 Murray St [Box 32]; Flr 6 - Rm L6-201-1, Toronto, ON M5T 3L9, Canada.
\end{abstract}

The original article can be found online at https://doi.org/10.1186/s1201 4-019-9246-0.

Published online: 17 July 2019

\section{Reference}

1. Music M, Soosaipillai A, Batruch I, et al. A proteome-wide immuno-mass spectrometric identification of serum autoantibodies. Clin Proteom. 2019;16:25. https://doi.org/10.1186/s12014-019-9246-0.

\section{Publisher's Note}

Springer Nature remains neutral with regard to jurisdictional claims in published maps and institutional affiliations.

\footnotetext{
*Correspondence: eleftherios.diamandis@sinaihealthsystem.ca

2 Department of Pathology and Laboratory Medicine, Mount Sinai Hospital, 60 Murray St [Box 32]; Flr 6 - Rm L6-201-1, Toronto, ON M5T 3L9,

Canada

Full list of author information is available at the end of the article
} 